\title{
Effect of row orientation on radiation interception and growth dynamics of wheat
}

\author{
Sarabjot Kaur Sandhu* and L.K. Dhaliwal \\ School of Climate Change and Agricultural Meteorology, Punjab Agricultural University, \\ LUDHIANA (PUNJAB) INDIA (Email : skchahal@pau.edu)
}

\begin{abstract}
The field experiments were conducted at Research Farm, School of Climate Change and Agricultural Meteorology during 2012-13 and 2013-14. This study was planned to know importance of row orientation in radiation interception and growth dynamics of wheat crop. Three wheat varieties viz., HD 2967, PBW 550 and PBW 343 were sown under two row orientation i.e. North-South (N-S) and East-West (E-W) on $25^{\text {th }}$ November during both crop seasons. PAR interception, dry matter accumulation and leaf area index were recorded at periodic intervals during both crop seasons. The PAR interception was more in east-west row orientation as compared to north-south row orientation in all the three varieties. Among different varieties, HD 2967 intercepted maximum photosynthetically active radiation due to highest leaf area index of crop. Relationships were developed between PAR interception and dry matter accumulation and leaf area index. Highly significant co-efficient of determination $\left(\mathrm{R}^{2}\right)$ were found and these $\mathrm{R}^{2}$-values indicated that PAR interception significantly influence dry matter accumulation as well as leaf area index of crop.
\end{abstract}

Key Words : Row orientation, PAR interception, Leaf area index, Dry matter accumulation

View Point Article : Sandhu, Sarabjot Kaur and Dhaliwal, L.K. (2018). Effect of row orientation on radiation interception and growth dynamics of wheat. Internat. J. agric. Sci., 14 (1) : 186-191, DOI:10.15740/HAS/IJAS/14.1/186-191.

Article History : Received : 01.05.2017; Revised : 29.11.2017; Accepted : 12.12.2017

* Author for correspondence: 